Gut, 1976, 17, 169-179

\title{
Duodenal ulcers: early and late onset
}

\author{
SHIU KUM LAM AND G. B. ONG \\ From the University Medical Unit and the University Surgical Unit, Queen Mary Hospital, Hong Kong
}

SUMMARY A hospital series of 1042 duodenal ulcer patients was examined to determine the relationship of the age of onset of ulcer dyspepsia with the blood group and with the family history of ulcer dyspepsia. It was found that those patients whose symptoms begin in the first two decades of life (early onset patients) contain a significantly larger proportion of group A, B, and AB subjects and a significantly stronger family history of dyspepsia than those whose symptoms begin from the fourth decade of life onwards (late onset patients), in whom blood group $\mathrm{O}$ prevails. The group $\mathrm{O}$ status is shown to be associated with a significant proneness to duodenal ulceration and a significant proneness to bleed, and in the late onset patients a significant proneness to bleed recurrently and severely. Bleeding is the predominent complication in the early onset patients. There is a significantly increased tendency for the late onset ulcers to perforate, to become stenosed, to have severe pain, and to be virulent - that is, to be multiple, post-bulbar, or giant. While these features do not appear to be related to the effect of ageing, the occurrence of associated gastric ulceration and the mortality rate was shown to be related.

It has been observed that one of the characteristics of familial peptic ulcer is early manifestation (Artemiev et al., 1970). In the majority of series of peptic ulcer in children, the investigators have been impressed by the frequency of a positive family history of peptic ulcer (Fällström and Reinand, 1961; Milliken, 1965; Habbick et al., 1968; Dogan et al., 1969; Sultz et al., 1970; Robb et al., 1972). Roberts et al.(1973), in contrast with other investigators(Fällström and Reinand, 1961; Habbick et al., 1968; Dogan et al., 1969) found that the incidence of blood group $\mathrm{O}$ was not significantly raised in their series of children with chronic duodenal ulcers compared with the controls. This is unlike the finding in the peptic ulcers of adults that there is an increased incidence of blood group O (Aird et al., 1954).

Lam and Sircus (1975), using their criterion of normal gastric acid secretory capacity expressed in relation to body weight, found that the hypersecreting duodenal ulcer patients, as compared with the normosecreting patients, had a significantly higher incidence of blood groups A, B, and AB, a significantly higher incidence of positive family history of ulcer dyspepsia, and a significantly earlier age of onset of ulcer symptoms. In addition, several investigators have shown that there is a strong relationship between blood group $\mathrm{O}$ and gastrointestinal

Received for publication 17 December 1975 bleeding and perforation in duodenal ulcer subjects (Clarke et al., 1956; Langman and Doll, 1965; Horwich et al., 1966; Lam and Sircus, 1975).

It thus appears that blood group, onset age of ulcer symptoms, and positive family history are some key factors in the understanding of duodenal ulceration. We therefore examined a hospital series of duodenal ulcer patients and studied the relationship between the onset age of ulcer symptoms and the blood group, family history of dyspepsia, as well as various complications of duodenal ulceration.

\section{Methods}

PATIENTS

A series of 1042 patients with duodenal ulceration proven by radiology, endoscopy, surgery, and/or necropsy were studied. These patients had been inpatients of the University Medical Unit and the University Surgical Unit at the Queen Mary Hospital, Hong Kong. Since there is a tendency for casualty doctors to admit patients with more surgical indications to the surgical ward, the advantage of studying both medical and surgical patients in a regional hospital is obvious. Because of the emergency nature of admissions to these units, these patients were usually admitted because they had developed either one or more of the following: gastrointestinal bleeding, acute perforation, pyloro- 
duodenal stenosis, or acute exacerbation of ulcer pain.

There were 822 males and 220 females with a mean age of $42 \cdot 2$ years \pm SD $17 \cdot 5$, The following clinical features were examined in each case.

\section{CLINICAL FEATURES EXAMINED}

1. Blood group: $\mathrm{O}, \mathrm{A}, \mathrm{B}$, or $\mathrm{AB}$.

2. Onset age of ulcer dyspepsia.

3. Age at, and duration of ulcer dyspepsia before, presentation to hospital.

4. Smoking habit. For the purpose of this study, smokers were those who smoked 10 or more cigarettes per day for the past two or more years, and heavy smokers were those who smoked 20 or more cigarettes per day for the past 10 or more years.

5. Alcohol consumers. These were patients who took four or more taels of double distilled rice wine or the equivalent (approximately $50 \mathrm{~g}$ ethanol) daily for the past two or more years.

6. The presence or otherwise of a family history of ulcer dyspepsia. This was also scored, giving one point for each first degree relative with dyspepsia, three points if either both parents or three or more first degree relatives were so affected.

7. Gastrointestinal bleeding: these patients were categorized into four groups: (1) those with silent bleeding - that is, no antecedent ulcer pain; (2) those with a single episode of bleeding; (3) those with more than one episode of bleeding; and (4) those in whom ulcer surgery had to be performed, either as an emergency or electively. All patients presented with spontaneous melaena and/or haematamesis. As not all patients had an endoscopic examination performed while bleeding, the evidence that the bleeding was due to peptic ulceration was only circumstantial.

8. Acute perforation. All cases were confirmed at laparotomy or necropsy.

9. Pyloroduodenal stenosis. All cases were confirmed at surgery.

10. Pain of such severity as to require inpatient management.

11. Whether or not these were virulent ulcers. We include multiple duodenal ulcers, giant ulcers (having a diameter of $3 \mathrm{~cm}$ and above), and postbulbar ulcers in this category.

12. Association with gastric ulceration as demonstrated by barium study, endoscopy and/or surgery.

13. Death, when this occurred as a result of the ulcer complication.

\section{STATISTICAL METHODS}

The Chi square test with Yates' correction where appropriate and Student's $t$ test were used.
Results

ONSET AGE OF ULCER DYSPEPSIA (Figure)

The distribution curve of the 1042 patients in relation to the onset age shows two unimpressive peaks, one in the second and the other in the fourth decade.

\section{ABO BLOOD GROUPS}

Blood group $\mathrm{O}$ was found in $51.4 \%$ of the patients. Compared with the blood group distribution in 2016 Chinese residents in Hong Kong (Chiu et al., 1974), there is a significantly $(\mathrm{P}<0.0005)$ larger proportion of group $\mathbf{O}$ in this series than expected (Table 1).

When the blood groups $\mathrm{A}, \mathrm{B}$, and $\mathrm{AB}$ are grouped together (506 patients) the highest density of the distribution occurs in the second decade, coinciding with the first peak of the distribution curve for onset age. The distribution of the 536 group $O$ patients is such that the constellation of group $\mathrm{O}$ is most dense in the 4th decade, coinciding with the second peak of the distribution curve for onset age (Figure).

The differences in proportion between blood groups A, B, AB taken together and blood group $\mathrm{O}$ in the various decades (first to ninth) are statistically significant $\left(\chi^{2}=38.53, \mathrm{P}<0.0005\right)$.

The mean age (Table 2) of onset is significantly lower in those with blood groups $\mathrm{A}, \mathrm{B}$, or $\mathrm{AB}$ than in those having group $O$. When each group is subdivided by sex, this difference is still significant for

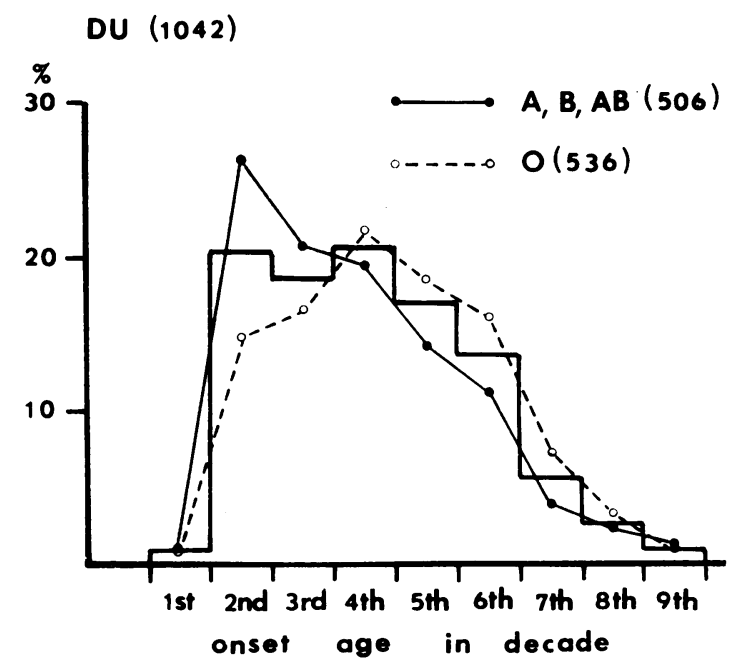

Figure Distribution of blood groups $A, B, A B$ (grouped together), and $O$ in 1042 duodenal ulcer patients superimposed on the distribution histogram of these patients in relation to the age of onset of ulcer dyspepsia ( $\chi^{2}$ for differences between $O$ and non- $O=38.53, \mathrm{P}<$ $0.0005)$. 


\begin{tabular}{|c|c|c|c|c|}
\hline Blood group & Control $(\%)$ & Early onset $(\%)$ & Late onset $(\%)$ & Total $(\%)$ \\
\hline $\begin{array}{l}\text { O } \\
\text { A } \\
\text { B } \\
\text { AB }\end{array}$ & $\left.\begin{array}{l}40^{1} \\
24 \cdot 7 \\
27 \cdot 2 \\
8 \cdot 1\end{array}\right\} 60^{2}$ & $\left.\begin{array}{r}38 \cdot 3^{3} \\
23 \cdot 0 \\
31 \cdot 5 \\
7 \cdot 2\end{array}\right\} 61 \cdot 7^{4}$ & $\left.\begin{array}{r}58 \cdot 3^{5} \\
19 \cdot 7 \\
19 \cdot 3 \\
2 \cdot 7\end{array}\right\} 41 \cdot 7$ & $\left.\begin{array}{r}51 \cdot 4^{6} \\
19 \cdot 9 \\
23.7 \\
5.0\end{array}\right\} 48.6$ \\
\hline Total nos. & 2016 & 222 & 621 & 1042 \\
\hline
\end{tabular}

Table 1 Blood group prevalence in early and late onset ulcers compared with controls

${ }^{1}$ and ${ }^{5} \mathrm{P}<0.0005 .{ }^{2}$ and ${ }^{4} \mathrm{P}$ not significant. ${ }^{3}$ and ${ }^{5} \mathrm{P}<0.0005 .{ }^{1}$ and ${ }^{6} \mathrm{P}<0.0005$.

\begin{tabular}{lrlll}
\hline & No. & Blood group & Total \\
\cline { 3 - 5 } & & $O$ & $A, B, A B$ & \\
\hline Males & 822 & $37 \cdot 2 \pm 15 \cdot 9^{1}$ & $33 \cdot 5 \pm 16 \cdot 3^{2}$ & $35 \cdot 3 \pm 16 \cdot 2^{3}$ \\
Females & 220 & $44 \cdot 7 \pm 18 \cdot 6^{4}$ & $40 \cdot 8 \pm 19 \cdot 2^{5}$ & $43 \cdot 3 \pm 18 \cdot 8^{6}$ \\
Total & 1042 & $39 \cdot 2 \pm 16 \cdot 9^{7}$ & $34 \cdot 6 \pm 17 \cdot 0^{8}$ & \\
\hline
\end{tabular}

Table 2 Age at onset of ulcer dyspepsia

$\begin{array}{ll}1 \text { and }{ }^{2} \mathrm{P}<0.0005 . & \text { and }{ }^{4} \mathrm{P}<0.0005 . \\ 4 \text { and }{ }^{5} 0.10>\mathrm{P}>0.05 . & \text { 2 and }{ }^{5} \mathrm{P}<0.0005 .\end{array}$

i and ${ }^{8} \mathrm{P}<0.0005$.

the males, but it just falls short of significance for the females. The mean onset age (Table 2) of the male patients is significantly lower than that of the females, and this holds true irrespective of whether they are group $\mathrm{O}$ or group $\mathrm{A}, \mathrm{B}$, or $\mathrm{AB}$.

The mean age at presentation to hospital (Table 3) is lower in those with blood group $\mathrm{A}, \mathrm{B}$, or $\mathrm{AB}$ than in those with blood group $O$. In relation to sex, this difference is still significant for the males, but just fails to reach significance for the females. The males on the average presented at a significantly earlier age than the females and this is so irrespective of their blood groups.

Because of these findings which suggest a possible relationship between age of onset of ulcer dyspepsia and blood grouping, two subgroups of patients were separated from the whole series: one subgroup whose onset age was 20 years or below-early onset group (222 patients) and another subgroup whose onset age was 31 years and above-the late onset group (621 patients). These two subgroups were compared in accordance with the clinical features listed in the methods section. A third subgroup is the one at the interphase-that is, those whose onset age is in the third decade of life. This was examined separately.

\section{ABO BLOOD GROUPS (Table 1)}

The late onset group has a significantly larger proportion of group $\mathrm{O}$ subjects than both the early onset group $(\mathrm{P}<0.0005)$ and the control population $(\mathrm{P}<0.0005)$. There is no significant difference between the early onset group and the control subjects in the proportion of blood groups they possess.

AgE AT PRESENTATION to hospital (Table 3) While the males presented at a significantly earlier age than the females in the full series $(\mathrm{P}<0.0005)$ as well as in the late onset patients $(\mathrm{P}<0.0005)$, this difference is not present in the early onset subjects.

\section{DURATION OF ULCER DYSPEPSIA}

The mean duration of ulcer dyspepsia in the early onset group (4.8 \pm SD 6.5 years) is not statistically different from that of the late onset group (4.9 \pm SD 5.8 years). No significant difference can be observed between the two groups when the duration is broken down into various periods (Table 4).

FAMILY HISTORY OF ULCER DYSPEPSIA (Table 5) The early onset ulcer subjects have a significantly higher frequency of positive family history of dyspepsia than the late onset patients $(P<0.0005)$, and this is still true when each group is further divided according to blood group. The score of the strength of positive family history is significantly higher in the early onset than in the late onset patients $(P<0.025)$.

There is no significant difference in the frequency of positive family history between group $\mathrm{O}$ and group $\mathrm{A}, \mathrm{B}$, and $\mathrm{AB}$ patients in the whole series or when this is subdivided into early and late onset groups. Patients with positive family history and those with negative history do not differ in their 


\begin{tabular}{llll}
\hline & $\begin{array}{l}\text { Males } \\
(822)\end{array}$ & $\begin{array}{l}\text { Females } \\
(220)\end{array}$ & Total \\
\hline Early onset (222) & $20 \cdot 8 \pm 7 \cdot 1^{1}$ & $20 \cdot 2 \pm 4 \cdot 5^{2}$ & $20 \cdot 8 \pm 7 \cdot 1$ \\
Late onset (621) & $51 \cdot 6 \pm 11 \cdot 8^{3}$ & $56 \cdot 9 \pm 13 \cdot 4^{4}$ & $53 \cdot 0 \pm 12 \cdot 4$ \\
Blood group & $42 \cdot 2 \pm 16 \cdot 3^{5}$ & $50 \cdot 2 \pm 18 \cdot 6^{6}$ & $44 \cdot 3 \pm 7 \cdot 3^{7}$ \\
O (536) & $38 \cdot 8 \pm 17 \cdot 0^{8}$ & $46 \cdot 5 \pm 19 \cdot 3^{\circ}$ & $40 \cdot 0 \pm 17 \cdot 6^{10}$ \\
A, B, AB (506) & $40 \cdot 4 \pm 16 \cdot 6^{11}$ & $48 \cdot 8 \pm 18 \cdot 99^{12}$ & $42 \cdot 2 \pm 17 \cdot 5$ \\
Total & &
\end{tabular}

Table 3 Age at presentation of symptoms (mean $\pm S D)$

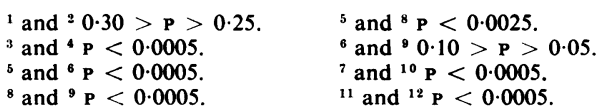

\begin{tabular}{lll}
\hline & \multicolumn{2}{l}{ Onset } \\
\cline { 2 - 3 } $\begin{array}{l}\text { Duration } \\
(y r)\end{array}$ & $\begin{array}{l}\text { Early (222) } \\
(\%)\end{array}$ & $\begin{array}{l}\text { Late }(621) \\
(\%)\end{array}$ \\
\hline$<1$ & $26 \cdot 1$ & $30 \cdot 0$ \\
$1-5$ & $38 \cdot 3$ & $34 \cdot 3$ \\
$6-10$ & $24 \cdot 3$ & $25 \cdot 9$ \\
$11-20$ & $8 \cdot 1$ & $8 \cdot 1$ \\
$>20$ & $3 \cdot 2$ & $1 \cdot 5$ \\
\hline
\end{tabular}

Table 4 Duration of ulcer dyspepsia in early and late onset patients*

* No significant difference between early and late groups in all duration periods.

blood group distribution, and both groups possess a significantly higher proportion of blood group $\mathrm{O}$ subjects than the control population (both $\mathrm{P}<$ 0.0005).

CIGARETTE SMOKING AND ALCOHOL CONSUMPTION (Table 6)

There is a significantly higher proportion of smokers in the late onset patients than in the early onset ones $(\mathrm{P}<0.0005)$. The proportion of heavy smokers is also significantly larger in the late onset patients $(\mathrm{P}<0.0005)$.

The late onset group has a significantly ( $\mathrm{P}<$ $0.0005)$ larger proportion of drinkers than the early onset group.

GASTROINTESTINAL BLEEDING (Table 7)

Among the total number of bleeders, $53.6 \%$ are of blood group $O$. In those patients who had no gastrointestinal bleeding (these are made up of patients presenting with perforation, stenosis, and severe pain), $45.7 \%$ are of blood group $O$. The difference between the bleeders and non-bleeders is significant $(P<0.0005)$. The proportion of bleeders having silent bleeding, a single episode of bleeding, and multiple episodes of bleeding is no different in those with blood group $O$ when compared with those who possess blood groups A, B, AB. However, those who underwent surgery either electively or as an emergency because of bleeding consist of more group $\mathrm{O}$ than non- $\mathrm{O}$ subjects $(\mathrm{P}<0.025)$.

In the early onset patients $87.8 \%$ presented with gastrointestinal bleeding, whereas $63.9 \%$ of the late onset patients presented with this problem. The

\begin{tabular}{|c|c|c|c|c|c|c|c|c|c|}
\hline \multirow{4}{*}{$\begin{array}{l}\text { Blood group } \\
\text { O (\%) } \\
\text { A, B, AB (\%) } \\
\text { Total no. }\end{array}$} & & \multicolumn{2}{|l|}{$\begin{array}{l}\text { Control } \\
\text { population }\end{array}$} & \multicolumn{2}{|c|}{$\begin{array}{l}\text { Ulcer } \\
\text { patients }\end{array}$} & \multicolumn{2}{|c|}{$\begin{array}{l}\text { Family } \\
\text { history }+ \text { ve }\end{array}$} & \multicolumn{2}{|c|}{$\begin{array}{l}\text { Family } \\
\text { history - ve }\end{array}$} \\
\hline & & $\begin{array}{r}40^{1} \\
60 \\
2016\end{array}$ & & $\begin{array}{r}51 \cdot 4 \\
48 \cdot 6 \\
1042\end{array}$ & & $\begin{array}{l}54 \cdot 1^{2} \\
45 \cdot 9 \\
292\end{array}$ & & $\begin{array}{l}50 \cdot 4^{3} \\
49 \cdot 6 \\
750\end{array}$ & \\
\hline & \multicolumn{3}{|c|}{ Main series } & \multicolumn{3}{|c|}{ Early onset } & \multicolumn{3}{|c|}{ Late onset } \\
\hline & $O$ & $A, B, A B$ & Total & $O$ & $A, B, A B$ & Total & $O$ & $A, B, A B$ & Total \\
\hline $\begin{array}{l}\text { No. } \\
\text { Family history + ve (\%) } \\
\text { Mean score }\end{array}$ & $\begin{array}{l}536 \\
29 \cdot 5^{*}\end{array}$ & $\begin{array}{l}506 \\
26 \cdot 5^{*}\end{array}$ & $\begin{array}{r}1042 \\
28 \cdot 0\end{array}$ & $\begin{array}{l}85 \\
51 \cdot 8^{\mathrm{a}}\end{array}$ & $\begin{array}{l}137 \\
45 \cdot 3^{b}\end{array}$ & $\begin{array}{l}222 \\
47.7 \dagger \\
1.49 \ddagger \\
\pm 0.07\end{array}$ & $\begin{array}{l}362 \\
21 \cdot 0^{c}\end{array}$ & $\begin{array}{l}259 \\
17 \cdot 0^{d}\end{array}$ & $\begin{array}{l}621 \\
19 \cdot 0 \dagger \\
1 \cdot 23 \ddagger \\
\pm 0.08\end{array}$ \\
\hline
\end{tabular}

Table 5 Family history of ulcer dyspepsia in relation to blood group and age of onset

\footnotetext{
${ }^{1}$ and ${ }^{2} \mathrm{P}<0.0005$. NS. a and ${ }^{\mathrm{C}} \mathrm{P}<0.0005$

1 and ${ }^{3} \mathbf{P}<0.0005 . \quad+P<0.0005 . \quad$ b and $d_{P}<0.0005$.

2 and ${ }^{3}$ NS. $\quad \ddagger P<0.025 . \quad a$ and $b$ NS.

NS $=$ Not significant ${ }^{c}$ and ${ }^{d}$ NS.
} 


\begin{tabular}{lcl}
\hline & \multicolumn{2}{l}{ Onset } \\
\cline { 2 - 3 } & Early & Late \\
\hline Total patients & 222 & 621 \\
Total smokers & $61^{*}$ & $438^{*}$ \\
Heavy smokers & $12 \dagger$ & $210^{\dagger}$ \\
Alcohol consumers & $12 \ddagger$ & $128 \ddagger$ \\
\hline
\end{tabular}

Table 6 Cigarette smokers and alcohol consumers in early and late onset ulcers

${ }^{*} \mathrm{P}<0.0005 . \dagger_{\mathrm{P}}<0.0005 . \ddagger \mathrm{P}<0.0005$.

difference is significant $(P<0.0005)$, and is still so when the patients are further divided by their blood group. Of the bleeders in the early onset group $15.4 \%$ came to surgery, while $33.8 \%$ of the bleeders in the late onset group required surgery. The difference is significant $(\mathrm{P}<0.0005)$, and holds true even when each group is divided according to blood group. No significant difference can be observed in the two groups regarding the proportion of silent bleeding, single bleeding, and multiple bleeding.
When each group is subdivided by their blood group, there is no significant difference in the proportion of silent bleeding, single bleeding, multiple bleeding, and surgically treated bleeders between the group $\mathbf{O}$ and the non-O subjects in the early onset group. In the late onset group, while this is still true as far as silent bleeding is concerned, there is a significant difference in the proportion of multiple bleeding $(P<0.05)$ and surgically treated bleeders $(\mathrm{P}<0.025)$ between the group $\mathrm{O}$ bleeders and those having the other blood groups.

\section{ACUTE PERFORATION (Table 8)}

Of the early onset patients $5.4 \%$ and $20.5 \%$ of the late onset patients had acute perforation. The difference is significant $(P<0.0005)$. This difference is still significant when each group is divided by their blood group.

There is no significant difference between the group $\mathrm{O}$ and non- $\mathrm{O}$ patients in the frequency of perforation in the main series. This is still true when

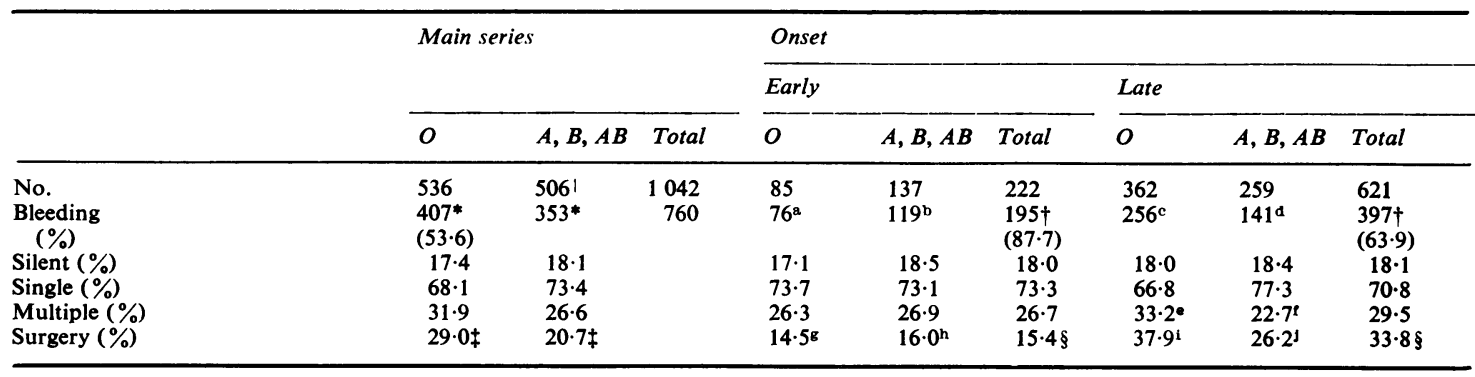

Table 7 Gastrointestinal bleeding: comparison between blood group $O$ and non- $O$ early and late onset

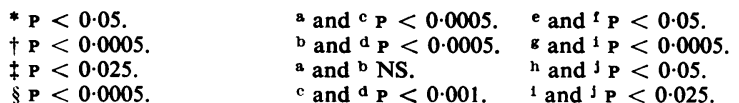

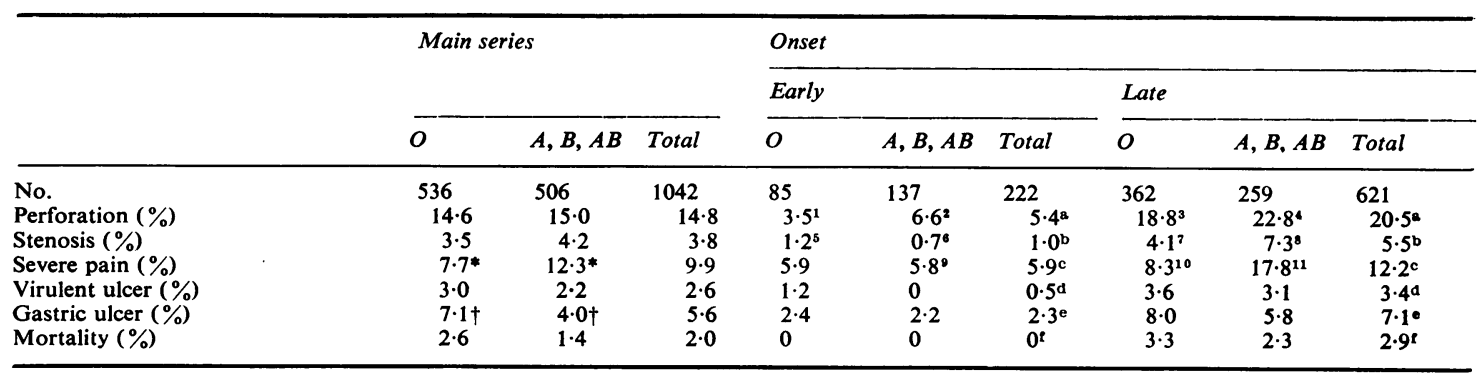

Table 8 Frequencies (in percentage) of various features in relation to blood group and time of onset

\footnotetext{
* $\mathbf{P}<0.05$.

$+\mathbf{P}<0.025$.

a $\mathbf{P}<0.0005$

b $P<0.01$.

c $P<0.025$.

d $P<0.05$.
}

\footnotetext{
e $\quad \mathbf{P}<0.025$.

$P<0.025$

1 and ${ }^{3} P<0.005$

2 and ${ }^{4} \mathrm{P}<0.0005$.

5 and ${ }^{7} P$ NS.

${ }^{6}$ and ${ }^{8} \mathrm{P}<0.01$.
} 
each group is broken down into early and late onset patients.

PYLORODUODENAL STENOSIS (Table 8)

One per cent of the early onset patients and $5.5 \%$ of the late onset patients had pyloroduodenal stenosis. This difference is significant $(P<0.01)$. When divided by their blood group, the late onset patients still have a higher frequency, but the difference reaches significance only in those with blood groups A, B, AB.

There is no significant difference between the group $\mathrm{O}$ and non-O patients in the frequency of stenosis, and this holds true even when the patients are subdivided into early and late onset groups.

SEVERE PAIN (Table 8)

In the early onset ulcer patients $5.9 \%$ and $12.2 \%$ of the late onset ulcer patients presented with severe pain. The difference is significant $(\mathrm{P}<0.025)$. When subdivided by their blood group, the late onset patients still have a higher frequency of severe pain, but the difference is statistically significant only in those having blood groups $\mathrm{A}, \mathrm{B}, \mathrm{AB}$.

The frequency of severe pain in group $A, B$, and $A B$ subjects is significantly higher than that in the group $O$ subjects $(P<0.05)$ and even more so in the late onset group $(\mathrm{P}<0.001)$. This is not present, however, in the early onset group.

VIRULENT ULCERS (Table 8)

There were 16 multiple ulcers, seven post-bulbar ulcers and four giant ulcers in this series. Of the early onset ulcer patients $0.5 \%$ and $3.4 \%$ of the late onset ulcer patients belong to the virulent category. The difference is significant $(P<0.05)$. A difference can still be observed when each group is divided by blood group, but it is not statistically significant in both instances.

There is no significant difference between the group $\mathrm{O}$ and non-O subjects in the incidence of virulent ulcers whether in the main series or when this is subdivided into early and late onset.

\section{ASSOCIATION WITH GASTRIC ULCERATION (Table 8)}

Of the early onset patients $2 \cdot 3 \%$ and $7 \cdot 1 \%$ of the late onset patients had associated gastric ulceration. The difference is significant $(P<0.025)$. A difference can still be observed when each group is divided by blood group, but in both instances the difference just falls short of statistical significance.

There is a significantly $(P<0.025)$ higher incidence of gastric ulceration in those with blood group $O$ than in those having blood groups $\mathrm{A}, \mathrm{B}, \mathrm{AB}$. When this is subdivided into early and late onset ulcers, those patients with blood group $\mathrm{O}$ still tend to have a higher incidence of associated gastric ulceration but in both instances the difference is not statistically significant.

\section{MORTALITY (Table 8)}

There is no mortality in the early onset patients as compared with a mortality of $2.9 \%$ in the late onset group. This difference is significant $(P<0.025)$.

There is no significant difference in mortality rate between the group $\mathrm{O}$ and non- $\mathrm{O}$ patients, be it in the whole series or when this is subdivided into early and late onset patients.

\section{RELATIONSHIP WITH ONSET AGE AND}

PRESENTING AGE (Tables 9 and 10)

The distribution in relation to the age of onset of ulcer dyspepsia of those with bleeding, acute perforation, pyloroduodenal stenosis, severe pain, virulent ulcers, gastric ulceration, and those who died from duodenal ulcer complications is shown in Table 9. The highest frequency of bleeding occurs in those whose onset is in the second decade of life. For the other features, a normal distribution is apparent with the peak occurring at the fourth (perforation, stenosis, severe pain, and virulent ulcers) and sixth (gastric ulceration, death) decades of life.

The relationship of these clinical features with the process of ageing is studied by calculating the percentage of the observed frequency of each feature in each decade of life upon the total number of patients presenting within that decade (Table 10). It is found that the frequency of surgery for bleeding, the rate of gastric ulceration, and the mortality rate rise with increasing age. In the case of bleeding, two peaks are observed, one occurring in the second and the other in the ninth decade. For the other clinical features, a normal distribution is apparent in each case.

PATIENTS AT INTERPHASE (Table 11)

This group is made up of the 199 patients whose onset age is in the third decade of life. The proportion of group $\mathrm{O}$ subjects $(44.7 \%)$ is no different from the control population ( $40 \%$ ) or from the early onset group $(38.3 \%)$ but is significantly $(\mathrm{P}<0.005)$ smaller than that in the late onset group $(58.3 \%)$. Examination of the frequencies of the various clinical features shows that this interphase group is similar to the early onset group, having more bleeding, less perforation, stenosis, severe pain, virulent ulcers, gastric ulcers, and death when compared with the late onset group. However, the differences reach statistical significance only in the case of bleeding $(P<0.0005)$ and perforation $(P<0.0005)$. 


\begin{tabular}{|c|c|c|c|c|c|c|c|}
\hline $\begin{array}{l}\text { Onset } \\
\text { age (yr) }\end{array}$ & Bleeding & Perforation & Stenosis & $\begin{array}{l}\text { Severe } \\
\text { pain }\end{array}$ & $\begin{array}{l}\text { Virulent } \\
\text { ulcers }\end{array}$ & $\begin{array}{l}\text { Gastric } \\
\text { ulcers }\end{array}$ & Death \\
\hline $\begin{array}{r}0-10 \\
11-20 \\
21-30 \\
31-40 \\
41-50 \\
51-60 \\
61-70 \\
71-80 \\
81-90\end{array}$ & $\begin{array}{r}1 \cdot 2 \\
24 \cdot 5 \\
22 \cdot 1 \\
17 \cdot 6 \\
14 \cdot 3 \\
11 \cdot 1 \\
5 \cdot 3 \\
2.6 \\
1 \cdot 3\end{array}$ & $\begin{array}{r}0 \\
7.8 \\
9.7 \\
26.6 \\
20.8 \\
18.2 \\
9 \cdot 7 \\
5.8 \\
1.3\end{array}$ & $\begin{array}{l}0 \\
5.0 \\
10.0 \\
32.5 \\
25.0 \\
20.0 \\
5.0 \\
2.5 \\
0\end{array}$ & $\begin{array}{c}0 \\
12 \cdot 6 \\
13 \cdot 6 \\
29 \cdot 1 \\
24 \cdot 3 \\
16 \cdot 5 \\
3 \cdot 9 \\
0 \\
0\end{array}$ & $\begin{array}{l}0 \\
11 \cdot 1 \\
11 \cdot 1 \\
29 \cdot 6 \\
18 \cdot 5 \\
14 \cdot 8 \\
11 \cdot 1 \\
3 \cdot 7 \\
0\end{array}$ & $\begin{array}{r}0 \\
8 \cdot 6 \\
13 \cdot 8 \\
17 \cdot 2 \\
17 \cdot 2 \\
22 \cdot 4 \\
12 \cdot 1 \\
5 \cdot 2 \\
3 \cdot 5\end{array}$ & $\begin{array}{l}0 \\
0 \\
9 \cdot 5 \\
9 \cdot 5 \\
14 \cdot 3 \\
23 \cdot 8 \\
19 \cdot 1 \\
14 \cdot 3 \\
9 \cdot 5\end{array}$ \\
\hline Total no. & 795 & 154 & 40 & 103 & 27 & 57 & 21 \\
\hline
\end{tabular}

Table 9 Distribution of various clinical features in relation to age of onset of ulcer dyspepsia (\% of total 1042)

\begin{tabular}{|c|c|c|c|c|c|c|c|c|c|c|}
\hline \multirow{2}{*}{$\begin{array}{l}\text { Presenting } \\
\text { age }(y r)\end{array}$} & \multirow[t]{2}{*}{ Total no. } & \multicolumn{3}{|c|}{ Bleeding } & \multirow{2}{*}{$\begin{array}{l}\text { Perfor- } \\
\text { ation }\end{array}$} & \multirow[t]{2}{*}{ Stenosis } & \multirow{2}{*}{$\begin{array}{l}\text { Severe } \\
\text { pain }\end{array}$} & \multirow{2}{*}{$\begin{array}{l}\text { Virulent } \\
\text { ulcers }\end{array}$} & \multirow{2}{*}{$\begin{array}{l}\text { Gastric } \\
\text { ulcers }\end{array}$} & \multirow[t]{2}{*}{ Death } \\
\hline & & Total & $\begin{array}{l}\text { Multiple } \\
\text { (\% total } \\
\text { bleeders) }\end{array}$ & Surgery & & & & & & \\
\hline $\begin{array}{l}11-20 \\
21-30 \\
31-40 \\
41-50 \\
51-60 \\
61-70 \\
71-80 \\
81-90\end{array}$ & $\begin{array}{r}138 \\
173 \\
189 \\
203 \\
179 \\
96 \\
48 \\
16\end{array}$ & $\begin{array}{l}95 \cdot 7 \\
83 \cdot 2 \\
74 \cdot 6 \\
64 \cdot 5 \\
55 \cdot 3 \\
64 \cdot 6 \\
77 \cdot 0 \\
87 \cdot 5\end{array}$ & $\begin{array}{l}34 \cdot 1 \\
43 \cdot 8 \\
45 \cdot 4 \\
38 \cdot 2 \\
47 \cdot 5 \\
37 \cdot 1 \\
24 \cdot 3 \\
35 \cdot 7\end{array}$ & $\begin{array}{l}14 \cdot 4 \\
16 \cdot 7 \\
37 \cdot 7 \\
42 \cdot 0 \\
56 \cdot 8 \\
61 \cdot 3 \\
51 \cdot 4 \\
71 \cdot 4\end{array}$ & $\begin{array}{r}3 \cdot 6 \\
8 \cdot 1 \\
14 \cdot 3 \\
19 \cdot 7 \\
22 \cdot 3 \\
18 \cdot 8 \\
16 \cdot 7 \\
12 \cdot 5\end{array}$ & $\begin{array}{l}0 \\
1 \cdot 2 \\
3 \cdot 2 \\
4 \cdot 9 \\
8 \cdot 4 \\
5 \cdot 2 \\
4 \cdot 2 \\
0\end{array}$ & $\begin{array}{r}0.7 \\
7 \cdot 5 \\
10 \cdot 1 \\
11 \cdot 8 \\
16 \cdot 8 \\
13 \cdot 5 \\
6 \cdot 3 \\
0\end{array}$ & $\begin{array}{l}0 \cdot 7 \\
1 \cdot 2 \\
1 \cdot 1 \\
3 \cdot 4 \\
5 \cdot 6 \\
4 \cdot 2 \\
2 \cdot 1 \\
0\end{array}$ & $\begin{array}{r}0.7 \\
2.9 \\
4.2 \\
5.9 \\
6 \cdot 1 \\
11 \cdot 5 \\
16.7 \\
18.7\end{array}$ & $\begin{array}{l}0 \\
0 \\
0.5 \\
1.0 \\
1 \cdot 1 \\
6 \cdot 3 \\
14.6 \\
25.0\end{array}$ \\
\hline
\end{tabular}

Table 10 Frequencies of various clinical features in relation to age at presentation ( $\%$ of total)

\begin{tabular}{|c|c|c|c|c|}
\hline & \multicolumn{2}{|l|}{ Blood group } & \multirow[t]{2}{*}{ Total } & \multirow[t]{2}{*}{$V s$ late onset } \\
\hline & $O$ & $A, B, A B$ & & \\
\hline No. & $89(44 \cdot 7 \%)^{*}$ & $110(55 \cdot 3 \%)^{*}$ & 199 & \\
\hline Perforation (\%) & 7.9 & $7 \cdot 3$ & $7 \cdot 5$ & $P<0.0005$ \\
\hline Stenosis (\%) & $3 \cdot 4$ & 0.9 & $2 \cdot 0$ & NS $\left(x^{2}=3.35\right)$ \\
\hline Severe pain (\%) & $6 \cdot 7$ & $7 \cdot 3$ & $7 \cdot 0$ & NS $\left(x^{2}=3.66\right)$ \\
\hline Virulent ulcer (\%) & $2 \cdot 3$ & $2 \cdot 7$ & $2 \cdot 5$ & NS \\
\hline Gastric ulcer $(\%)$ & 7.9 & 1.8 & $4 \cdot 5$ & NS \\
\hline Mortality (\%) & $2 \cdot 3$ & 0.9 & $1 \cdot 5$ & NS \\
\hline Bleeding (no.) & $75(84 \cdot 3 \%)$ & $93(84.6 \%)$ & $84 \cdot 4$ & $P<0.0005$ \\
\hline Silent $(\%)$ & $16 \cdot 0$ & $17 \cdot 2$ & $16 \cdot 7$ & NS \\
\hline Single $(\%)$ & $66 \cdot 7$ & $67 \cdot 7$ & $67 \cdot 3$ & NS \\
\hline Multiple (\%) & $33 \cdot 3$ & $32 \cdot 3$ & $32 \cdot 7$ & NS \\
\hline Surgery $(\%)$ & $13 \cdot 3$ & $18 \cdot 3$ & $16 \cdot 1$ & $P<0.0005$ \\
\hline
\end{tabular}

Table 11 Duodenal ulcers with onset age at third decade (interphase group)

No significant difference between $O$ and non-O, interphase group, and early onset group in any one feature. * Vs late onset group $P<0.005$, vs control and early onset group both NS. NS = not significant.

\section{Discussion}

This study once again confirms the original discovery by Aird et al. (1954) of an increased incidence of blood group $O$ in patients with duodenal ulcer when compared with the normal population. In addition, it offers further evidence that a familial tendency of ulcer dyspepsia is associated with early onset of ulcer symptoms (Artemiev et al., 1970).

Of great interest is the finding in this study that the age of onset of ulcer dyspepsia is related to blood group (Figure). A higher frequency of blood group
$\mathbf{O}$ occurs in patients whose onset of ulcer dyspepsia begins from the fourth decade onwards (late onset patients) than in those whose ulcer dyspepsia takes place in the first two decades of life (early onset patients). In the latter group, blood groups A, B, and $\mathrm{AB}$ predominate (Table 1). The early onset group, however, is no different from the control population in their blood group distribution. This is consistent with the findings of Roberts et al. (1973) that the incidence of blood group $\mathrm{O}$ was not significantly raised in their large series of children with chronic duodenal ulcer. However, that a relation- 
ship between age of onset and blood group must exist is obvious from the observation (Table 2) that the mean onset age of all patients with blood groups $A, B$, or AB is significantly lower than the mean onset age of group $O$ patients, and that this is uninfluenced by sex. It thus appears that the possession of blood group $\mathrm{O}$ delays the onset age. It is interesting to note that female patients have a greater mean onset age than male patients irrespective of their blood group. That female ulcer patients tend to present at a later age than males had been observed (Doll et al., 1951). In our study also the mean age at presentation to hospital is significantly higher in females (48.8 years \pm SD 18.9) than in males $(40.4$ years \pm SD 16.6) (Table 3). However, when the patients are divided into early onset and late onset groups, the sex difference disappears in the early onset subjects, suggesting that whatever be the pathogenetic mechanism leading to early ulceration it is uninfluenced by sex.

That duodenal ulceration has a familial tendency has been well recorded in the literature (Doll and Buch, 1950; Doll and Kellock, 1951; Kuenssberg, 1962; Sklaroff, 1963; Veselý et al., 1968; Gillies and Skyring, 1969; Kubícková and Veselý, 1972). Our study shows that the early onset patients have a significantly higher frequency of and stronger family history of ulcer dyspepsia (Table 5). This agrees with previous studies on adult patients with duodenal ulcer (Artemiev et al., 1970; Lam and Sircus, 1975) and agrees in principle with the findings in most paediatric series as quoted in the introductory section of this paper that children with duodenal ulcer have a very strong family history of the disease. We did not demonstrate any relationship between familial tendency and blood group. This is at variance with the findings of the only other reported study which examined this relationship and which showed that group $\mathbf{O}$ duodenal ulcer patients have a significantly higher frequency of a positive family history of dyspepsia than do the non-O patients (Kubícková and Veselý, 1972). Furthermore, we could not confirm the findings by these authors that the distribution of the blood groups in the patients with a negative family history was similar to that in the control population, whereas those with a positive family history had a significantly higher proportion of group $\mathbf{O}$ than the controls. In our series, the blood group distribution is similar both in patients with a positive family history and in those with a negative one (Table 5). This aspect clearly needs further evaluation. Lam and Sircus (1975), expressing maximum acid output in terms of body weight, showed that duodenal ulcer patients with blood group A, B, and AB are associated with acid hypersecretion and that these patients have an earlier age of onset and a stronger family history of ulcer dyspepsia than do the normosecreting patients, in whom blood group $\mathrm{O}$ prevails. These findings have been confirmed in a series of Chinese duodenal ulcer patients (Lam, 1974) ${ }^{1}$. It has been shown that those with a family history of ulcers are more prone to acid hypersecretion (Lander and Maclagan, 1934; Fodor et al., 1968; Artemiev et al., 1970). These findings, together with our present observations, support the concept that the early onset ulcer patients form a distinct group: the ulcers tend to be familial, they tend to be associated with blood groups $\mathrm{A}, \mathrm{B}$, or $\mathrm{AB}$, and with hypersecretion. The interrelationship between these factors remains to be defined. It is tempting to speculate that acid hypersecretion is more linked with blood group and that familial tendency is more related to the earliness in onset.

In the late onset group, while we have no evidence that a genetically linked mechanism is operating except for the prevalence of blood group $\mathrm{O}$, environmental factors may play a significant role. Some support for this contention is seen in this study, in that cigarette smokers, including heavy smokers and habitual alcohol consumers, are more prevalent in the late onset patients (Table 6). These two factors may be aetiologically related to peptic ulceration (Brown et al., 1957; Woodward et al., 1957; Doll, 1964; Monson, 1970). In addition, belonging to the female sex appears to delay the onset of ulcer pain and the presentation of complications.

It is tempting to speculate that the possession of blood group $\mathrm{O}$, notwithstanding its deleterious effects, has a protective mechanism acting against excessive parietal cell hyperplasia, hence the finding of a normal but upward-shifted acid secretory capacity (Lam and Sircus, 1975) and hence the finding in this study of a delay in the onset of ulcer symptoms.

The rest of the study is an attempt to determine whether or not there is any clinical significance in dividing patients into early and late onset groups. This is done by examining the relation of these two groups with the known complications of duodenal ulcer, the frequency of virulent ulcer, the frequency of associated gastric ulceration, and the mortality rate.

It has been found that gastrointestinal bleeding occurs more commonly in ulcer patients with blood group $\mathbf{O}$ than in those who possess the other blood groups (Clarke et al., 1956; Langman and Doll, 1965; Horwich et al., 1966; Lam and Sircus, 1975). This association is again demonstrated in this series $(P<0.05)$. However, while this association is even

${ }^{1}$ But not so in another Scottish series (Prescott et al.) calling urgently for further studies. 
more exaggerated in the late onset patients $(P<$ 0.001 ), it is not significant in the early onset group (Table 7). In this series also a significantly larger proportion of group $\mathrm{O}$ than non-O bleeders came to surgery electively or as an emergency because of the bleeding. Again this difference is obvious in the late onset group, but becomes insignificant in the early onset bleeders. Furthermore, in the late onset group but not in the early onset one, group $O$ patients have a significantly higher frequency of multiple bleeding. All these imply that possessing group $O$ plays a less important role in the bleeding occurring in the early onset subjects but it imparts to the late onset ulcer patients a proneness to bleed and a proneness to bleed more frequently and more severely. One possible explanation is the presence of a much older population in the late onset group (Table 3). If the occurrence of multiple bleeding and surgery be related to the effect of ageing, one would expect it to rise in frequency with increasing age. Table 10 shows that this is certainly true for surgery but not so for multiple bleeding. We cannot exclude the possibility that the unknown pathogenetic mechanisms involved in the late onset ulcers are responsible for the more severe bleeding in these patients.

In the early onset patients $87.8 \%$ present with gastrointestinal bleeding, a proportion that is significantly higher than that in the late onset group (Table 7). This is likely to be the result of a disproportionate lack of the other complications in the early onset patients. It is of interest to note that there is no difference in the frequency of silent, single, and multiple bleeding between the early and late onset patients, as well as between group $\mathbf{O}$ and non- $\mathrm{O}$ subjects, save for the difference with respect to multiple bleeding in the late onset group just mentioned.

There is no prevalence of blood group $\mathrm{O}$ among the acute perforators either in the main series or in the early and late onset groups (Table 8). The proneness of group $\mathbf{O}$ patients to acute perforation has been observed but cannot be taken as established (Horwich et al., 1966; Langman et al., 1967; Evans et al., 1968; Lam and Sircus, 1975). The proportion of patients presenting with perforation is significantly higher in the late onset than in the early onset patients irrespective of their blood group (Table 8). The distribution of all the perforations in relation to onset age is such that the peak frequency occurs at the fourth decade (Table 9), where the late onset patients are most dense. That this is unrelated to the ageing process is obvious in Table 10, which shows that the observed frequency forms a normal distribution in relation to the age of the patients.

A similar relationship with blood group and with the early and late onset ulcers exists for pyloroduodenal stenosis, severe pain, and virulent ulcers (Table 8). Similarly, while the distributions of these features in relation to onset age are such that the peak frequencies occur in the fourth decade of life (Table 9), the failure of these features to rise in incidence with advancing age (Table 10) suggests that their occurrence is unrelated to the ageing process. In the late onset group, blood group $A, B$, and $A B$ patients have a significantly higher proportion of severe pain than in the blood group $O$ subjects. This feature is difficult to explain, since the exact mechanism of ulcer pain is not fully understood and the proportion having confined perforation as a cause of intractability is not known, as not all patients with pain underwent surgery.

We have considered post-bulbar ulcers and giant ulcers (larger than $3 \mathrm{~cm}$ in diameter) as virulent ulcers, as they are prone to develop complications (Ramsdell et al., 1957; Cooke and Hutton, 1958; Berkowitz and Glassman, 1962; Mistilis et al., 1963; Pattison and Stellar, 1966). Of the 16 patients with more than one duodenal ulcer, five presented with pyloroduodenal stenosis and the rest with bleeding. All except one patient with bleeding underwent surgery because of the complications. We, therefore, include multiple ulcers in the virulent category.

It is unlikely that the difference in all these features between the early onset and late onset patients could be ascribed to a difference in duration of the disease, since the duration of dyspepsia before presentation to hospital is similar in the two groups (Table 4).

There is a significantly higher frequency of gastric ulceration in those with blood group $\mathrm{O}$ than in those with groups $\mathbf{A}, \mathbf{B}, \mathbf{A B}$ (Table 8). This trend is still obvious, though insignificant, when the patients are divided into early and late onset groups. Our findings support the general concept that there is a higher prevalence of blood group $\mathbf{O}$ in patients whose gastric ulcers are associated with duodenal ulcers, as was reviewed by McConnell (1965). In addition, the late onset patients have a significantly larger proportion of gastric ulceration, suggesting that the lateness of onset plays a significant role. However, while the distribution of the gastric ulcers in relation to onset age is such that the peak frequency occurs in the sixth decade (Table 9), the observed frequency is obviously related to the actual age of the patient (Table 10). This indicates that the effect of ageing is responsible for the more frequent occurrence of gastric ulceration in the late onset group. This agrees with the findings of Mowat et al. (1975).

The late onset patients have a significantly higher mortality rate than the early onset ones (Table 8). This is unrelated to their blood group, since no difference can be demonstrated between the $\mathrm{O}$ and 
non-O patients. However, this is most probably due to the more advanced age of the patients in the late onset group, since the mortality rate is directly related to the age of the patient (Table 10).

Analysis of the 199 patients whose age of onset is in the third decade of life-that is, the interphase group (Table 11) - is of interest. The proportion of blood group $\mathrm{O}(\mathbf{4 4 . 7 \%})$, though similar to that in the early onset group $(38.3 \%)$ and significantly different from that in the late onset group (58.3\%), has manifestly shifted towards the late onset group. A similar trend can be observed for the various clinical features. It is therefore a true intermediate group and serves as further evidence that the early and late onset groups are distinct subdivisions in duodenal ulceration. It is to be stressed that the onset age is but one criterion for subdividing duodenal ulcers. There may appear other criteria-one example is the acid secretory capacity (Sircus, 1968; Lam and Sircus, 1975); another is the functioning $G$ cell mass (Byrnes, et al., 1976). There is a great need to identify all these criteria and categorize duodenal ulcers appropriately, as this will obviously have an important bearing on the management of this disease.

It thus appears that blood group $O$ is associated with a proneness to ulcerate and a proneness to bleed, and, in the late onset patients, a proneness to bleed severely. The lateness in the onset of ulcer symptoms is related to a tendency to perforate, to become stenosed, to have severe pain, and to be virulent. The occurrence of gastric ulceration and the mortality rate is related to the effect of ageing.

The explanation for the early appearance of the early onset ulcers can only be speculative. It is unrelated to sex. A strong genetic predisposition appears to be obvious from our study. It is perhaps this, plus the right environment, which brings forth its appearance. It is tempting to speculate that, in the late onset ulcers as compared with the early onset group, the acid-peptic force is met by a weaker mucosal defence resulting in more complications and more virulence.

We should like to thank our colleagues of the Departments of Medicine and Surgery for their support in this study and for the use of data relating to patients in our combined charge. To Dr Thomas K. W. Ng, FIS (U.K.), of the Department of Community Medicine, University of Hong Kong, we owe much for his patient tutorial on statistical methods, but any errors in this study are of our own making.

\section{References}

Aird, I., Bentall, H. H., Mehigan, J. A., and Roberts, J. A. F. (1954). The blood groups in relation to peptic ulceration and carcinoma of colon, rectum, breast and bronchus. British Medical Journal, 2, 315-321.

Artemiev, E. N., Vildt, M. O., Potyakina, N. N., and Musnitskaya, E. N. (1970). The importance of hereditary factor in the pathogenesis of peptic ulcer. Soviet Medicine, 33 (4), 54-58.

Berkowitz, D., and Glassman, S. (1962). Giant duodenal ulcers. Gastroenterology, 42, 743.

Brown, R. G., McKeown, T., and Whitfield, A. G. W. (1957). A note on the association between smoking and disease in man in the seventh decade. British Journal of Preventive and Social Medicine, 11, 162-164.

Byrnes, D. J., Lam, S. K., and Sircus, W., (1976). Studies on duodenal ulcers. II. Gastrin response to protein meal. Clinical Science and Molecular Medicine (in press).

Chiu, D. T. J., Yeung, K. Y., and Lee, C. F. (1974). Distribution of blood groups and $\mathrm{Rh}$ factor of Chinese in Hong Kong. Asian Journal of Modern Medicine, 10, 407.

Clarke, C. A., Edwards, J. W., Haddock, D. R. W., HowelEvans, A. W., McConnell, R. B., and Sheppard, P. M. (1956). ABO blood groups and secretor character in duodenal ulcer. British Medical Journal, 2, 725-731.

Cooke, L., and Hutton, C. F. (1958). Postbulbar duodenal ulceration. Lancet, 1, 754-757.

Dogan, K., Oberiter, V., Najman, E., Dogan, S., Buneta, L., Rudar, D., and Mark, B. (1969). Some characteristics of peptic ulcer in children. Lijecnicki Vjesnik, 91, 1045-1058.

Doll, R. (1964). Medical treatment of gastric ulcer. Scottish Medical Journal, 9, 183-196.

Doll, R., and Buch, J. (1950). Hereditary factors in peptic ulcer. Annals of Eugenics, 15, 135.

Doll, R., Jones, F. A., and Buckatzsch, M. M. (1951). Occupational factors in the aetiology of gastric and duodenal ulcers. Medical Research Council. Special Report Series, No. 276. HMSO: London.

Doll, R., and Kellock, T.D. (1951). The separate inheritance of gastric and duodenal ulcers. Annals of Eugenics, 16. 231-240.

Evans, D. A. P., Horwich, L., McConnell, R. B., and Bullen, M. F. (1968). Influence of the ABO blood groups and secretor status on bleeding and on perforation of duodenal ulcer. Gut, 9, 319-322.

Fällström, S. P., and Reinand, T. (1961). Peptic ulcer in children. Acta Paediatrica Scandinavica, 50, 431-436.

Fodor, O., Vestea, S., Urcan, S., Popescu, S., Sullica. S. Iencica, R., Goia, A., and Ilea, V. (1968). Hydrochloric acid secretion capacity of the stomach as an inherited factor in the pathogenesis of duodenal ulcer. American Journal of Digestive Diseases, 13, 260-265.

Gillies, M. A., and Skyring, A. (1969). Gastric and duodenal ulcer. The association between aspirin ingestion, smoking and family history of ulcer. Medical Journal of Australia, 2, 280-285.

Habbick, B. F., Melrose, A. G., and Grant, J. C. (1968). Duodenal ulcer in childhood. Archives of Disease in Childhood, 43, 23-27.

Horwich, L., Evans, D. A. P., McConnell, R. B., and Donohoe, W. T. A. (1966). ABO blood groups in gastric bleeding. Gut, 7, 680-685.

Kubícková, A., and Veselý, K. T. (1972). The value of investigations of the incidence of peptic ulcer in the families of patients with duodenal ulcer. Journal of Medical Genetics, 9, 38-42.

Kuenssberg, E. V. (1962). Are duodenal ulcer and chronic bronchitis family diseaes? Proceedings of the Royal Society of Medicine, 55, 299-302.

Lam, S. K. (1974). Clinical and Pathophysiological Studies on Duodenal Ulcers: Evidence for the Existence of Two Populations, p. 46. Thesis, University of Hong Kony.

Lam, S. K., and Sircus, W. (1975). Studies on duodenal 
ulcers. I. The clinical evidence for the existence of two populations. Quarterly Journal of Medicine, 44, 369-387.

Lander, F. P. L., and MacLagan, N. F. (1934). One hundred histamine test-meals on normal students. Lancet, 2, 12101213.

Langman, M. J. S., and Doll, R. (1965). ABO blood group and secretor status in relation to clinical characteristics of peptic ulcer. Gut, 6, 270-273.

Langman, M. J. S., Doll, R., and Saracci, R. (1967). ABO blood group and secretor status in stomal ulcer. Gut, $\mathbf{8}$, 128-132.

McConnell, R. B. (1965). Genetics and gastroenterology. In Recent Advances in Gastroenterology, pp. 1-23. Edited by J. Badenoch and R. N. Brook. Churchill: London.

Milliken, J. C. (1965). Duodenal ulceration in children. Gut, 6, 25-28.

Mistilis, S. P., Wiot, J. F., and Nedelman, S. H. (1963). Giant duodenal ulcer. Annals of Internal Medicine, 59, 155164.

Manson, R. R. (1970). Cigarette smoking and body form in peptic ulcer. Gastroenterology, 58, 337-334.

Mowat, N. A. G., Needham, C. D., and Brunt, P. W. (1975). The natural history of gastric ulcer in a community: a four-year study. Quarterly Journal of Medicine, 44, 45-56.

Pattison, A. C., and Stellar, C. A. (1966). Surgical management of postbulbar duodenal ulcers. American Journal of Surgerv, 111, 313-318.

Ramsdeli, J. A., Bartholomew, L. G., Cain, J. C., and Davis,
G. D. (1957). Postbulbar duodenal ulcer. Annals of Internal Medicine, 47, 700-710.

Robb, J. D. A., Thomas, P. S., Orszulok, J., and OdlingSmee, G. W. (1972). Duodenal ulcer in children. Archives of Disease in Childhood, 47, 688-696.

Roberts, D. F., Jackson, R. H., and Cowan, W. K. (1973). Genetics of duodenal and gastric ulcer, In Clinics in Gastroenterology, pp. 539-546. vol. 2, W. B. Saunders: London.

Sircus, W. (1968). Gastric secretion in peptic ulcer disease with special reference to the influence of body weight, duration of disease and stenosis. In Physiology of Gastric Secretion, pp. 581-591. Edited by L. S. Semb and J. Myren. Universitetsforlaget: Oslo.

Sklaroff, S. A. (1963). Use of National Health Service general practice records in epidemiological inquiries: duodenal ulcer-a test case. British Journal of Preventive and Social Medicine, 17, 177-184.

Sultz, H. A., Schlesinger, E. R., Feldman, J. G., and Mosher, W. E. (1970). The epidemiology of peptic ulcer in childhood. American Journal of Public Health and Nation's Health, 60, 492-498.

Veselý, K. T., Kubičková, A., and Dvoráková, M. (1968). Clinical data and characteristics differentiating types of peptic ulcer. Gut, 9, 57-68.

Woodward, E. R., Robertson, C. Ruttenberg, H. D., and Schapiro, H. (1957). Alcohol as a gastric secretory stimulant. Gastroenterology, 32, 727-737. 